Francis of Marchia and William of Ockham:

Fragments from a Dialogue*

\title{
ROBERTO LAMBERTINI
}

\section{Abstract}

It is well known that Francis of Marchia and William of Ockham joined Michael of Cesena's rebellion against the pope, together escaping from Avignon and signing documents supporting Cesena's defence of Franciscan poverty. The relationship between the works of the two thinkers, on the other hand, is the subject of ongoing investigation. After discussing Francis' rejection in his Commentary on the Sentences of Ockham's theory of quantity, this paper shows how Francis' Improbatio became a source for Ockham's Opus Nonaginta Dierum. Building on Offler's ground-breaking critical edition of the latter work, it is argued that Ockham made extensive use of Francis' Improbatio, even though on several points he felt it necessary to reformulate the arguments of his confrère or even to substantially modify his positions. The two Franciscan theologians differed deeply both in their basic philosophical commitments and in their methodological attitude. These differences emerged even when they were - so to speak - fighting on the same front.

Some decades ago, in her ground-breaking study of the reception of William of Ockham's thought, Anneliese Maier devoted an interesting section to Francis of Marchia. She pointed out that Francis, in his treatment of the Eucharist, was probably the first author to take Ockham's innovative interpretation of quantity into consideration; Francis discusses at length and eventually rejects Ockham's theory of quantity, which plays an important role in the latter's interpretation of the Eucharist. ${ }^{1}$ In 1963

* This article was made possible by the kindness, help and patience of many people, in particular Chris Schabel and Russ Friedman. I also wish to thank Carlo Dolcini and Andrea Tabarroni for their constant encouragement. I have already presented some of the contents of the present contribution in Italian in Nonnumquam impugnantium diversorum personas assumpsi: Francesco d'Ascoli come fonte del pensiero politico di Ockham, in: Pensiero Politico Medievale, 1 (2003), 97-140, but in a rather different context.

1 A. Maier, Metaphysische Hintergründe der spätscholastischen Philosophie, Rome 1955, 199-209; cf. also eadem, Zu einigen Problemen der Ockhamforschung, in: eadem, Ausgehendes Mittelalter, 
Hilary S. Offler was able to enrich the apparatus of his critical edition of Ockham's Opus Nonaginta Dierum with references to Francis' Improbatio (a reply to the papal bull Quia vir reprobus), ${ }^{2}$ then still unedited and almost unknown. In this way Maier and Offler revealed traces of a dialogue between two Franciscan theologians who also shared an important political decision, the adhesion to Michael of Cesena's rebellion against Pope John XXII. The present paper presents some further evidence concerning this "dialogue," although the picture remains fragmentary, focusing in particular on its second phase, that is on the relationship between the Improbatio and the Opus Nonaginta Dierum. The stress of this article will be placed not only on doctrinal similarities, but also on parallel passages that show how Ockham used the work of his fellow refugee.

\section{De corpore Christi}

Since Maier's and Offler's pivotal studies, many contributions have enriched our picture of the discussion between Francis and Ockham. Jürgen Miethke and Gedeon Gál showed that Maier's important discovery solved only in part the difficult problems of chronology connected to Ockham's and Francis' commentaries on the Sentences. ${ }^{3}$ In particular, they discarded the complex cluster of hypotheses that in Maier's opinion would have explained the supposed cross-references between the two commentaries. The only thing that now seems beyond doubt is that Francis, in writing his commentary, was aware of Ockham's work, and not vice-versa. More recently, Paul Bakker was able to situate the dissension between the two Minorite

vol. 1, Rome 1964, 188-91, originally published in: Archivum Franciscanum Historicum 46 (1953), 161-94.

${ }^{2}$ Cf. Guillelmus de Ockham, Opus Nonaginta Dierum, in Guillelmi de Ockham Opera Politica, II, eds. J.G. Sikes and H.S. Offler, Manchester 1963, "Introduction," xviii: “. . . another Michaelist theologian, Francis of Ascoli, composed a full-scale attack on Quia vir which in its systematic criticism of the text may well have provided Ockham with the immediate pattern for OND, as it clearly did with ideas and authorities in abundance." In the following, I will refer to this edition simply as Opus Nonaginta Dierum.

${ }^{3}$ J. Miethke, Ockhams Weg zur Sozialphilosophie, Berlin 1969, 23-29; G. Gál, Praefatio, in: Guillelmi de Ockham Quaestiones in librum quartum Sententiarum (Reportatio), eds. R. Wood, G. Gál, and R. Green, St. Bonaventure, NY 1984, 16*-17*; E. Iserloh, Gnade und Eucharistie in der philosophischen Theologie des Wilhelm von Ockham. Ihre Bedeutung für die Ursachen der Reformation, Wiesbaden 1956, 24-26. See also W.J. Courtenay, Ockham, Chatton, and the London Studium: Observations on Recent Changes in Ockham's Biography, in: Die Gegenwart Ockhams, eds. W. Vossenkuhl and R. Schönberger, Weinheim 1990, 327-37. 
theologians in the wider context of competing interpretations of the Eucharist. Specifically, Bakker showed that Francis of Marchia supported a slightly modified version of Scotus' theory concerning the inherence of accidents. ${ }^{4}$ In this context, although far from being a faithful follower of Scotus, ${ }^{5}$ Francis rejected Ockham's interpretation of quantity, which is hardly compatible with the basic assumptions of Scotus' metaphysics. Current investigations of the various surviving versions of Francis of Marchia's commentary on Book IV of the Sentences may shed more light on the precise moment that Francis learned of the new position held by his English confrére at Oxford. ${ }^{6}$ Perhaps in the future we will be able to establish whether Francis came across Ockham's opinion while delivering his Parisian lectures of 1319-20, or whether this happened later on, while he was revising his lectures into a Scriptum. ${ }^{7}$ In the latter case, Francis' criticism would be even closer chronologically to the year in which Ockham was summoned to Avignon,- which was also related to his theories concerning the Eucharist. ${ }^{8}$

4 P.J.J.M. Bakker, La raison et le miracle. Les doctrines eucharistiques (c. 1250-c. 1400). Contribution à l'étude des rapports entre philosophie et théologie, vol. 1, Nijmegen 1999, especially 122-32, 389408; cf. also Fabrizio Amerini's article and the Introduction in this volume.

${ }^{5}$ Cf. R.L. Friedman, Francis of Marchia and Fohn Duns Scotus on the Psychological Model of the Trinity, in: Picenum seraphicum, 18 (1999), 11-56.

${ }^{6}$ Cf. R.L. Friedman and C. Schabel, Francis of Marchia's Commentary on the Sentences: Question List and State of Research, in: Mediaeval Studies, 63 (2001), 31-106. The problems stemming from the complex tradition of Francis' commentary have not yet been solved; the interesting contribution by N. Mariani, Certezze ed ipotesi sul Commento alle Sentenze di Francesco della Marca OMin., in: Archivum Franciscanum Historicum, 95 (2002), 93-183, is far from compelling; cf. C. Schabel, The Redactions of Book I of Francesco d'Appignano's Commentary on the Sentences, in: D. Priori and M. Balena (eds.), Atti del II Convegno Internazionale su Francesco d'Appignano, Appignano del Tronto 2004, 97-122; R.L. Friedman, Principia and Prologue in Francesco d'Appignano's Sentences Commentary: The Question 'Quaeritur utrum ens simpliciter simplex possit esse subiectum alicuius scientiae', ibidem, 123-49.

${ }^{7}$ For example, Maier was persuaded that Francis refers to Ockham's Tractatus de corpore Christi; given the chronology accepted today, this would mean that Francis must have written this quaestio after 1323-4; this date is, in fact, the conclusion of C. Grassi, Introductio, in Guillelmi de Ockham Tractatus de Quantitate et Tractatus de Corpore Christi (Opera Theologica, X), St. Bonaventure, NY 1986, 23*-28*. The problem is that Francis' passage referring to Ockham is not a literal quotation, but rather a free rendering.

${ }^{8}$ For Ockham's trial in Avignon, cf. J. Koch, Neue Aktenstücke zu dem Gegen Wilhelm Ockham in Avignon geführten Prozess, in: Recherches de Théologie ancienne et médiévale, 7 (1935), 353-80, and 8 (1936), 79-93. now in: id. Kleine Schriften, vol. 2, Rome 1973, 275-365; See also W.J. Courtenay, The Academic and Intellectual Worlds of Ockham, in: P.V. Spade (ed.), The Cambridge Companion to Ockham, Cambridge et alibi 1999, 17-30. 


\section{From Avignon to Munich}

At any rate, it seems highly plausible that Ockham and Francis were both in Avignon by 1324, the former because of the investigation into his doctrines, the latter most probably on account of the task of teaching theology at the local Franciscan Studium. ${ }^{9}$ Nevertheless, we have no evidence of contacts between the two theologians until the dramatic change in their lives that resulted from Michael of Cesena's rebellion against John XXII. As is well known, the English friar, who was on trial in Avignon, and the Italian master of theology, who most probably owed at least his title to Michael of Cesena, ${ }^{10}$ fled from Avignon together and temporarily found safe haven in the Ghibelline city of Pisa. From this time on their names appear together in several collective documents signed in support of Michael's denunciation of John XXII as a heretic. In the first of these documents, which Knysh considers - although with no compelling arguments - a backdated forgery made by the rebel friars to justify their action ex post facto, Francis and Ockham appear only as witnesses. ${ }^{11}$ The Appellations from Pisa, however, carry the signatures of both theologians as supporters of Michael's appeal. ${ }^{12}$ Ockham and Francis also appear as

9 See footnote 11 for a piece of evidence concerning Francis' position in Avignon. For 1324 as a commonly accepted date for the beginning of his activity in Avignon, cf. P. Vian, Francesco della Marca, in: Dizionario Biografico degli Italiani, vol. 49, Rome 1997, esp. 794. Nevertheless, the issue deserves deeper investigation.

10 According to the investigations of B. Roest, A History of Franciscan Education (c. 12101517), Leiden-Boston-Köln 2000, 102, we know that during Michael's generalate the choice of the candidate for what specialists call the "degree course," leading to the magisterium, rested with the minister general.

11 Edited in Nicolaus Minorita: Chronica. Documentation on Pope Fohn XXII, Michael of Cesena and the Poverty of Christ with Summaries in English. A Source Book, eds. G. Gál and D. Flood, St. Bonaventure, NY 1996, 182-89, at 189: "Acta, gesta et facta fuerunt praedicta coram religiosis et honestis viris, fratribus Ordinis Minorum, Francisco de Esculo, in sacra theologia doctore et lectore tunc in conventu Fratrum Minorum de Avenione, Guillelmo Ocham, in sacra pagina magistro..." Henceforth I will refer to this edition simply as Chronica. G. Knysh, Biographical rectifications concerning Ockham's Avignon Period, in: Franciscan Studies, 46 (1986), 82-85, and, against Knysh, J. Miethke, Ockhams Perspektiven oder Engführung in eine falsche Richtung? Eine Polemik gegen eine neuere Publikation zu Ockhams Biographie, in: Mittellateinisches Jahrbuch, 29 (1994), 77-78. Actually, Miethke's article is a reaction to G. Knysh, Ockham Perspectives, Winnipeg 1994, a book which is difficult to find; Prof. Knysh himself very kindly sent a copy of the book to me, and I am grateful, although I do not share many of his views. Cf. E.L. Wittneben, Bonagratia von Bergamo. Franziskanerjurist und Wortführer seines Ordens im Streit mit Papst Fohannes XXII, Leiden-Boston 2003, pp. 282-83.

12 Cf. Appellatio in forma maiori, Nicolaus Minorita, Chronica, 423: "Cui appellationi et provocationi incontinenti adhaeserunt et eam approbaverunt religiosi viri frater Franciscus de Esculo, doctor in sacra pagina, et Guillelmus de Ockham de Anglia, magister in sacra 
co-authors of the Allegationes religiosorum virorum. ${ }^{13}$ These texts of varying length, which most probably were the result of a team effort led by Bonagratia da Bergamo, do not allow us to establish, let alone evaluate, the contributions of the individual co-authors. They merely inform us that Francis and Ockham agreed on the basic tenets of Michael's position, which they themselves were endeavoring to corroborate with their arguments.

The situation changes after 16 November 1329, the date of publication of the papal bull Quia vir reprobus, which claimed to refute Michael's arguments in a definitive way. ${ }^{14}$ Now the group, which in the meantime was settling in Munich, not only reacts with a collective work known as Appellatio magna, ${ }^{15}$ but also produces some works that have only one author. There are several clues suggesting that Francis of Marchia, in his Improbatio, may have been the first to write against Quia vir reprobus, even before the Munich Appeal was made public on 26 March 1330. In particular, the existing parallel passages in the two treatises, and even more in the rough draft of the Appellatio magna preserved in Vat. lat. 4009, strongly suggest that it was Bonagratia who reworked some passages from Francis into the Appellatio magna, and not the reverse. Indeed, taking into consideration the interpretation of a dialogue between Pontius Pilate and Jesus concerning the nature of the latter's kingship, it is possible to see a sort

pagina ..."; the same wording is in the Appellatio in forma minori, ibidem, 455. It is worth noting that the Chronica calls Ockham "magister in sacra pagina"; many scholars (e.g. Miethke, Ockhams Weg (cit. n. 3 above), 29-34, but also Courtenay, The Academic (cit. n. 8 above), 25, seems to agree with Miethke) believe the contrary The author of the Chronica could have been inaccurate in his effort to stress the academic prestige of the friars who rebelled against John XXII; the problem, however, would deserve a deeper investigation which would not be appropriate in this contribution.

It must be added that these subscriptions are not available in the entire manuscript tradition. Concerning the criteria followed by Gál and Flood in this edition, see J. Miethke, Der erste vollständige Druck der sogennanten 'Chronik des Nicolaus Minorita' (von 1330/1338). Bemerkungen zur Präsentation eines 'Farbbuches' des 14. Jahrhunderts, in: Deutsches Archiv, 54 (1998), 623-42.

${ }^{13}$ Cf. Allegationes religiosorum virorum, in Nicolaus Minorita, Chronica, 524: "Allegationes religiosorum virorum, fratrum Henrici de Thalheim, Francisci de Apponiano [the edition wrongly has 'Appomano'], dicti de Esculo, Guillelmi de Ockham in sacra pagina magistrorum ..."

${ }_{14}$ Quia vir reprobus, in Nicolaus Minorita, Chronica, 553-613; this papal bull has been edited several times, not only in Bullarium Franciscanum V by C. Eubel, but also together with Ockham's Opus Nonaginta Dierum and Francis' Improbatio. For differing reasons, none of these editions can be considered "critical."

15 Edition in Nicolaus Minorita, Chronica, 624-866. Henceforth "Appellatio magna." 
of evolution from Francis' Improbatio, which describes the episode in terms of a university disputatio, to the Munich Appeal, which adopts the setting of a legal interrogation instead. The rough draft seems to represent a middle stage in this evolution, since in many passages it changes Francis' disputatio terminology into the processual one. ${ }^{16}$

If this is true, then Francis must have worked at a very quick pace to have at least part of his work incorporated in the Munich Appeal. ${ }^{17}$ At any rate, in January of 1331 Michael of Cesena refers explicitly to Francis' Improbatio as an already available refutation of John XXII's Quia vir reprobus, although the manuscript tradition actually transmits an unfinished-but almost complete - work. $^{18}$ It is beyond any doubt, however, that Ockham wrote his Opus Nonaginta Dierum after Francis and after the Munich Appeal. As Offler showed many years ago, the Venerabilis Inceptor uses both treatises as sources for his own refutation of the papal bull Quia vir reprobus. ${ }^{19}$

The relationship is therefore practically reversed with respect to the previous one between their commentaries on the Sentences: there Francis, informed of the innovative theory of his English confrére, rejects it as untenable. In Munich, it is Ockham who is acquainted with the work of his fellow refugee and uses it for his own treatise. In the latter case, however, they are not fighting on different sides, but support the same position: the defence of the Franciscan theory of poverty against John XXII.

${ }^{16} \mathrm{I}$ argued in favor of this thesis, putting forward evidence in support, in Francesco d'Ascoli e la polemica francescana contro Giovanni XXII: a proposito dei rapporto tra l'Improbatio' $e$ l'Appellatio magna monacensis', in: A. Degrandi, O. Gori, G. Pesiri, A. Piazza and R. Rinaldi (eds.), Introd. by O. Capitani, Studi in onore di Girolamo Arnaldi offerti dalla Scuola nazionale di studi medioevali, Rome 2001, 277-308.

17 Cf. Lambertini, Francesco d'Ascoli e la polemica (cit. n. 16 above), 300-5.

18 Francisci de Esculo OFM Improbatio contra libellum domini Iohannis qui incipit 'Quia vir reprobus', ed. N. Mariani OFM, Grottaferrata (Rome) 1993; this is the first product of Mariani's praiseworthy attempt to make Francis' works available to a wider public; see also Francisci de Marchia sive de Esculo Quodlibet cum quaestionibus selectis ex commentario in librum Sententiarum, ed. N. Mariani, Grottaferrata (Rome) 1997; Sententia et compilatio super libros Physicorum Aristotelis, ed. N. Mariani, Grottaferrata (Rome) 1998; Commentarius in IV libros Sententiarum Petri Lombardi. Quaestiones preambulae et prologus, ed. N. Mariani, Grottaferrata (Rome) 2003. Concerning Mariani's editions, see the review article by C. Schabel, Notes on a Recent Edition of Parts of Francis of Marchia's In Primum Librum Sententiarum, in: Picenum seraphicum, 19 (2000), 277-82, and Atti del II Convegno Internazionale su Francesco d'Appignano (cit. n. 6 above), especially 97-147. Most recently Mariani published two sermons attributed to Francis: Due Sermoni attribuiti a Francesco della Marca, in: Archivum Franciscanum Historicum, 98 (2005), 571-95.

${ }_{19}$ Offler, Introduction, in: Guillelmi de Ockham Opus Nonaginta Dierum, xvii-xviii. 
As I will show, Ockham draws inspiration from Francis' Improbatio, but shapes his rationes in a new way. As is well known to students of Ockham, his Opus Nonaginta Dierum attempts to give a sort of impartial account of the discussion, presenting the opposing arguments of John XXII and his impugnatores as if Ockham himself were not involved in the debate. John Kilcullen speaks of "recitative works," recalling that, at the same time, Ockham is himself one of these "attackers." 20 Offler had already underlined the ambiguity that arises from the approach of the Venerabilis Inceptor. ${ }^{21}$ As far as Francis' Improbatio is concerned, Ockham does not confine himself to describing Francis' rationes, but often reshapes them, in an attemptas it seems - to improve them. Ockham is well aware of the fact that, while concurring in condemning John XXII's position, the impugnatores sometimes disagree on the reason why John is wrong. Consequently he claims to have exposed on occasion the positions of different impugnatores, who try to refute the pope in diverging ways. ${ }^{22}$ Given this kind of disclaimer, the structure of Opus Nonaginta Dierum appears even more layered, as Ockham not only presents the discussion as if he were not one of the impugnatores, but also reports the disagreements among them. This notwithstanding, he formulates anew many arguments, and in so doing he also reveals his own position. ${ }^{23}$

This second "fragment" of the "dialogue" between Francis and Ockham is therefore even more complex than the first, since is not a clear-cut opposition of two competing accounts of a fundamental aspect of the Eucharistic miracle, but rather a refinement of arguments that are supposed to serve the same purpose. In the following I will therefore focus on some cases in which Ockham further develops some of Francis' positions, which will go on to play an important role in Ockham's political thought.

\section{Dominium and dominia}

In his Ockhams Weg zur Sozialphilosophie, Miethke rightly stressed the seminal importance of the passages from the Opus Nonaginta Dierum in which Ockham criticizes Pope John's interpretation of the origins of ownership

${ }^{20} \mathrm{~J}$. Kilcullen, The Political Writings, in: The Cambridge Companion to Ockham (cit. n. 8 above), 302-25.

${ }^{21}$ Offler, Introduction (cit. n. 19 above), xv.

22 Opus Nonaginta Dierum, c. 124, 857.

${ }^{23}$ Cf. my Nonnumquam impugnantium diversorum personas assumpsi (cit. in the asterisk note above). 
among human beings. ${ }^{24}$ The Venerabilis Inceptor, in fact, outlined his own theory of the origins of society and power starting from his critique of John's views. Many tenets of Ockham's position, which not by chance he presents as the position of the impugnatores (that is, those who accuse John XXII of heresy), in fact derive from Francis' Improbatio. The discussion concerning the nature of the original relationship of mankind to things offers a telling example. The first texts produced by the group around Michael described this relationship in terms of absence of dominium. In implementing Bonaventure's distinction between usus facti and dominium, they distinguished between the prelapsiarian state, in which human beings merely used things, and the postlapsarian one, where dominium was introduced as a consequence of $\sin .^{25}$ John XXII reacted to this account: referring to the passages in Genesis where God says: "Dominamini piscibus maris," John therefore concluded that dominium already existed before the Fall. The only difference that was brought about by Original Sinaccording to John - was the division of a common dominium into different dominia. ${ }^{26}$ Francis of Marchia had to take this objection into account. Indeed, the Improbatio is the first "Michaelist" text that speaks of two dominia. ${ }^{27}$ While denouncing the papal position as heretical, Francis implicitly admits that it is right to speak of dominium even in the prelapsarian state. He observes, however, that there are two kinds of dominia, which differ radically from each other. ${ }^{28}$ The first kind of dominium marked the

${ }^{24}$ Miethke, Ockham's Weg (cit. n. 3 above), 467-77.

25 See e.g. Appellatio in forma maiori, published in 1328, edited in Nicolaus Minorita, Chronica, 239-40: "Et quod sicut antequam esset peccatum non erat appropriatio rerum temporalium introducta, sed fuisset habitus usus rerum usu consumptibilium et non consumptibilium absque aliqua proprietate, sic fuit in apostolis et apostolicis viris"; for commentary see. B. Töpfer, Urzustand und Sündenfall in der mittelalterlichen Gesellschafts- und Staatstheorie, Stuttgart 1999, esp. 431-68; J. Miethke, Paradiesischer Zustand-Apostolisches ZeitalterFranziskanische Armut. Religiöses Selbstverständnis, Zeitkritik und Gesellschaftstheorie im 14. Fahrhundert, in: F.J. Felten, N. Jaspert, and S. Haarländer (eds.), Vita Religiosa im Mittelalter. Festschrift für Kaspar Elm zum 70. Geburtstag, Berlin 1999, 505-32; cf. also G.L. Potestà, The State of Innocence and Private Property in the Polemic on Evangelical Poverty at the Beginning of the Fourteenth Century, in: F.R. Psaki and C. Hindley (eds.), The Earthly Paradise. The Garden of Eden from Antiquity to Modernity, Binghamton, NY, 2002, 149-63.

${ }^{26}$ Cf. Töpfer, Urzustand und Sündenfall (cit. n. 25 above), 433-36.

${ }_{27}$ Cf. my La povertà pensata: Evoluzione storica della definizione dell'identità minoritica da Bonaventura ad Ockham, Modena 2000, 205-18.

${ }^{28}$ Improbatio, 153: 'Consimiliter dominium introductum 'per iniquitatem,' siue proprium siue commune, est alterius generis a dominio communi naturali omnium quod fuisset si homo non peccasset, et distat ab eo plus quam acetum a uino, quia se habet ad illud sicut corruptibile ad incorruptibile, et diuisibile ad indiuisibile." 
prelapsarian state in which human beings not only shared things in use, but were so deeply tied to one another by brotherly love that even their feelings could be shared, and everyone rejoiced in the happiness of the others. Francis summarizes his position very well in the following passage:

... quilibet gaudebat de comodo alterius sicut de suo, et solacium unius redundasset in singulos: et ita gaudium cuiuslibet rei fuisset commune omnibus per participationem mutue consolationis, iuxta illud: "Ecce quam bonum et quam iocundum abitare fratres in unum." (...) Et ita, si homo non peccasset, fuissent omnia communia tripliciter, scilicet, quoad dominium, quoad potestatem utendi et quoad commune solacium rerum. Et post peccatum, per oppositum, tripliciter facta est divisio: quoad appropriationem dominii, quoad appropriationem iuris utendi et quoad appropriationem solatii et gaudii, quod homines male affectati nolunt alteri communicare. ${ }^{29}$

In his Opus Nonaginta Dierum Ockham begins his description of the position of the impugnatores with the distinction between two kinds of dominium. As Miethke remarked in 1969, Ockham prefers the expression "alterius rationis" to the "alterius generis" that Francis uses. ${ }^{30}$ This could also be a distant echo of the divergent philosophical attitudes of the two theologians; ${ }^{31}$ more relevant differences emerge, however, in what follows. First of all, Ockham focuses his attention not on the bonds among human beings, as Francis does, but on the relationship between mankind and nature. According to Ockham, in the prelapsarian state animals and plants obeyed human beings spontaneously, and in this sense the human community then exerted a kind of dominium that ceased to exist after the Fall. ${ }^{32}$ On this basis, Ockham can describe the transition from innocence

\section{Improbatio, 155.}

${ }^{30}$ Miethke, Ockhams Weg (cit. n. 3 above), 470; cf. Opus Nonaginta Dierum, c. 28, 492-93: "Sed dicunt isti impugnatores quod hic, sicut in aliis, cavillose procedit. Non enim appellans negat in omni sensu primos parentes in statu innocentiae dominium temporalium habuisse; sed negat ipsos habuisse dominium, quod vocatur 'proprietas'... Dominium autem, quod habuerunt primi parentes in statu innocentiae, est totaliter alterius rationis ab isto dominio." For Marchia's alterius generis, see n. 28 above. Surprisingly enough, the recent G. Geltner, Eden Regained: William of Ockham and the Franciscan Return to Terrestrial Paradise, in: Franciscan Studies, 59 (2001), 63-89, is silent about this source for Ockham and inaccurate in many respects.

31 Ockham's preference for "ratio" instead of "genus" could perhaps be linked to the different ontological and semantical presuppositions underlying Francis' and Ockham's theologies; the whole issue, however, requires closer scrutiny.

32 Opus Nonaginta Dierum, c. 14, 432: "Ad cuius evidentiam dicunt [scil. impugnatores] esse sciendum quod dominium omnium temporalium datum primis parentibus fuit potestas rationabiliter regendi et gubernandi temporalia absque eorum resistentia violenta, ita quod homini violentiam vel nocumentum inferre non poterant." Cf. A. Brett, Liberty, Right and Nature. Individual Rights in Later Scholastic Thought, Cambridge et alibi 1996, 66-68, who analyzes this point; her conclusions, however, deserve further examination. 
to the fallen state in a more nuanced way than Francis did in the Improbatio. Not just two, but three distinct stages should be considered: before the Fall mankind already enjoyed an almost unlimited dominium over creation. Immediately afterwards, in order to obviate the difficulties of the new state, God gave human beings the power to distribute things and to appropriate them. Remarking that one could call this power "dominium" as well, even though it would be an improper use of the term, Ockham seems not only to criticize John XXII, but also implicitly to correct Francis. Ockham's third stage, which corresponds to the present situation in the fallen state, can be described in terms of a plurality of dominia. ${ }^{33}$

To sum up, Ockham is well aware of Francis' response to John's objection regarding the original dominium; while sharing the basic tenet of his position - i.e. that the dominium of the prelapsarian state is radically different from the one that characterizes the fallen state - he modifies it in several ways. In particular, Ockham's stress on the fact that before the Fall nature was at the unconditional disposal of mankind avoids the risks of what Tierney calls "primitivism": i.e. the view that the prelapsarian state can be completely restored after the Fall. ${ }^{34}$ This view could be inferred from the writings of previous "Michaelist" authors, ${ }^{35}$ and had already been

33 Opus Nonaginta Dierum, c. 14, 439: "Et ita fuit triplex tempus: scilicet ante peccatum, in quo tempore habuerunt dominium, quale numquam aliqui habuerunt postea. Secundum tempus fuit post peccatum et ante rerum divisionem; et in illo tempore habuerunt potestatem dividendi et appropriandi sibi res, et si talis potestas vocetur dominium, potest concedi quod habuerunt dominium commune rerum. Tertium tempus fuit post divisionem rerum, et tunc inceperunt dominia propria, qualia nunc sunt mundanorum."

${ }^{34}$ B. Tierney, The Idea of Natural Rights. Studies on Natural Rights, Natural Law, and Church Law, 1150-1625, Atlanta 1997, 162. For interesting critical remarks on Tierney's interpretation, see Wittneben, Bonagratia von Bergamo (cit. n. 11 above), 298-9. For a recent discussion of Ockham's theory, see C.J. Fernandez, Ockham's Theory of Property, in: Pensiero Politico Medievale, 2 (2004), 147-59.

${ }^{35}$ This is what one reads, for example, in: Appellatio in forma maiori, in Nicolaus Minorita, Chronica, 239: “. . . apostoli eorumque discipuli, et sanctus Clemens una cum eis et omnibus volentibus vitam apostolicam imitari, assumpserunt et servaverunt quantum ad hoc statum qui fuit ante peccatum, scilicet antequam per iniquitatem introductum esset quod aliquis diceret hoc meum proprium et hoc tuum. Qui status fuit status innocentiae sive legis naturae ..."; L. Oliger, Fr. Bonagratia de Bergamo et eius Tractatus de Christi et Apostolorum paupertate, in: Archivum Franciscanum Historicum, 22 (1929), 292-335, 487-511; esp. 496-97: "Нос etiam probatur ex ratione. Nam filius Dei ad hoc naturam humanam assumpsit, ut genus humanum quod per peccatum a statu innocentie exciderat, repararet. Set non perfecte et convenienter reparasset nisi assumpsisset naturam innocentem, ergo talem assumpsit. Unde Augustinus super Iohannem ecce Agnus Dei: Si agnus, ergo innocens. Set si assumpsit naturam innocentem, assumpsit eam secundum omnem perfectionem anime, quam habuisset aliquis in statu innocentie. Set in statu innocentie fuissent homines sine dominiis distinctis, 
rejected by critics of the Franciscan position, such as Durand of $\mathrm{St}$ Pourçain. ${ }^{36}$ Ockham, in fact, never admits that we can return to the state that obtained before the Fall. Even the Apostolic community, which represents the highest level of perfection attainable in this life, had to live in a world where the original harmony was irrevocably lost.

\section{Per iniquitatem}

Among the canones of the Decretum regarding the nature and origin of ownership, the passage known as Dilectissimis, taken from a forgery attributed to Pope Clement I, is surely one of the most influential. In this passage one reads that "per iniquitatem alius dixit hoc esse suum et alius istud ..." ${ }^{37}$ There had already been a lively discussion among the canonists concerning the exact meaning of the expression "per iniquitatem" in this context, and this discussion emerged again in the confrontation between the pope and the Michaelists. John attacked the interpretation Bonagratia had given to this passage in the Appellatio minor, stating that it is wrong to say, as Bonagratia did on behalf of his Minister General, that "per iniquitatem" in this context means that the division of property depends on human positive law. Instead, John maintained that "per iniquitatem" refers to the Original Sin, "peccatum primorum parentum."

sicut patet VIII di., c. 1 etc. Igitur si Christus tenuit statum innocentie, non habuit dominium distinctum in speciali vel in communi alicuius rei, set solum simplicem usum facti eorum"; a little later, p. 506: "Illum statum habuit Christus in quantum homo et apostoli postquam statum perfectionis assumpserunt, quem fuit possibile habere, quem homines de iure nature et divino habuissent, et non quem habuerunt propter iniquitatem, cum Christus innocens et perfectissimus assumpserit et docuerit apostolos suos vitam innocentissimam et perfectissimam, qua perfectior numquam fuit nec excogitari posset."

${ }^{36}$ Cf. Töpfer, Urzustand und Sündenfall (cit. n. 25 above), 425-29. Durandus' text is edited in J. Miethke, Das Votum De paupertate Christi et Apostolorumdes Durandus von Sancto Porciano im theoretischen Armutsstreit. Eine dominikanische Position in der Diskussion um die Franziskanische Armut (1322/3), in: S. Jenks, J. Sarnowsky, and M.L. Laudage (eds.), Vera Lex Historiae. Studien zu mittelalterlichen Quellen. Festschrift für Dietrich Kurze zu seinem 65. Geburtstag, KölnWien-Weimar 1993, 149-96, esp. 173: "Non est igitur verisimile, quod Christus in se et in apostolis reduxerit mundum ad statum innocentie, quantum fuit possibile, immo elegit pro se et apostolis paupertatem, afflictiones et miserias corporales, que sunt statui innocentie omnino contraria."

37 An excursus about this text is in Töpfer, Urzustand und Sündenfall (cit. n. 25 above), esp. 174-5. For the discussions among the canonists about the origin of property, see R. Weigand, Die Naturrechtslehre der Legisten und Dekretisten von Imerius bis Accursius und von Gratian bis Iohannes Teutonicus, München 1967, esp. 307-36.

38 Quia vir reprobus, in Nicolaus Minorita, Chronica, 593-94: "Ex hoc dicit ipse quod divisio temporalium est facta per ius humanum, quod dicitur iniquum, et contra aequitatem 
Marchia, who himself does not entirely avoid the use of expressions such as "dominium introductum per iniquitatem" or "introductum per peccatum," "39 answers that the Sin must be considered the origin, not the immediate cause, of the institution of the postlapsarian dominium. ${ }^{40}$ According to Francis, John XXII, who claims on the contrary that Original Sin is the immediate cause of dominium, contradicts himself in various ways. ${ }^{41}$

Here again Ockham refers to the opinion of the impugnatores; one passage is an almost literal echo of Francis. In the Opus Nonaginta Dierum we read that, according to the impugnatores, "hic per propria verba convincitur," while the Doctor Succinctus had written "se ipsum conuincit." Nevertheless, the main objection Ockham directs at John is not the same as Francis', because Ockham sees the contradiction in the fact that, on one hand, John denies the human origin of property division and, on the other, insists on its being immediately caused by Original Sin. ${ }^{42}$ In contrast, Francis had remarked that the pope had spoken of Adam as the first owner of property, before Eve was created. ${ }^{43}$ Ockham does not limit himself to this, but expands on the subject, recalling the two interpretations of "per iniquitatem" available in the Glossa ordinaria to Gratian's Decretum and already quoted in the Pisan Appellatio in forma maiori. The Glossa in fact listed the possible interpretation of iniquitas as a custom contrary to natural equity, or as sollicitudo. Ockham remarks that the pope does not

iuris naturalis. Dicimus quod hoc est falsum, quia per iniquitatem non intelligitur ius gentium, sed intelligitur peccatum primorum parentum per quod natura corrupta fuit." This is one of the few passages in which John XXII refers to the Appellatio in forma maiori, and not, as usual, to the shorter version, known as "appellatio in forma minori"; cf. Appellatio in forma maiori, in Nicolaus Minorita, Chronica, p. 239. Mariani, Improbatio, p. 372, footnote 34, refers imprecisely to the Appellatio in forma minori, although he remarks that the reference was "ad sensum."

39 Improbatio, pp. 153-54.

40 Improbatio, p. 156: " $3^{\circ}$, effundit uenenum suum in eo quod dicit, quod ista diuisio rerum facta est per peccatum primorum parentum': quod, si intelligat mediate et originaliter, uerum est, quia peccatum cupiditatis uel superbie, quo ista diuisio immediate introducta est, descendit originaliter ex radice peccati originalis, sicut cetera alia peccata; si autem intelligat immediate et directe, sicut intelligere uidetur, prout in sequentibus magis apparebit, falsum est et erroneum, quia tunc talis diuisio rerum fuisset facta immediate in paradiso: quod non inuenitur."

41 Improbatio, p. 373.

42 Opus Nonaginta Dierum, c. 92, p. 669.

${ }^{43}$ Improbatio, p. 373: “. . . ergo ante peccatum primorum parentum non fuit aliquod dominium proprium et, per consequens, Adam, antequam peccaret, non habuit aliquod dominium temporalium proprium: cuius oppositum ipse dicit hic. Et ita se ipsum conuincit." 
follow the Glossa ordinaria in his interpretation, but suggests a meaning, the identification of iniquitas with Original Sin, that can be true only in a particular sense, that is that the peccatum parentum was the occasio of the introduction of property division. The real cause was indeed the human will. $^{44}$

Following a different strategy, Ockham comes to the same result as Francis in this case: without sin there would have been no property division, but the canon Dilectissimis cannot mean that sin immediately brought property division into existence. The substantial agreement of the two Franciscan theologians on this seemingly abstruse exegetical problem is important, because it is connected to a much deeper problem, that of the role of the human will and initiative in establishing different dominia. As we shall see below, this is a core question of the dispute.

\section{Humanum et divinum}

Improbatio, pp. 376-377

Set quod immediate prima diuisio dominiorum propriorum sit introducta, ante diluuium et post diluuium, iure humano et non iure diuino nisi mediate, quo modo omnia iura sunt a Deo, patet, quoniam prima diuisio dominiorum, que legitur in scriptura, ante diluuium fuit divisio inter Abel et Caym: ante quam diuisionem, non legitur aliqua alia divisio dominiorum prior. Illa autem diuisio non legitur fuisse facta immediate auctoritate diuina, set magis uoluntate humana, quia quod Caym esset agricola et Abel pastor ovium, sicut legitur Genesis iiii capite, hoc non diuino iussu set magis humano instinctu factum est, eo quod Caym, terrenus et terrena diligens,
Opus Nonaginta Dierum, 88, p. 656

Secunda conclusio, quam probant, est quod primum dominium temporalium proprium post lapsum fuit iure humano seu ordinatione humana aut voluntate humana introductum. Hanc probant sic: Prima divisio dominiorum, quae legitur in scriptura, fuit inter Abel et Cain. Sic enim legitur Genesis iv: Fuit autem Abel pastor ovium et Cain agricola. Factum est autem post multos dies ut offerret Cain de fructibus terrae munera Deo. Abel quoque obtulit de primogenitis gregis sui, et de adipibus eorum; et respexit Dominus ad Abel, et ad munera eius. Ad Cain autem, et ad munera illius, non respexit. Ex hiis verbis colligitur quo isti duo habuerunt rerum divisarum distincta dominia. Sed non

44 Opus Nonaginta Dierum, c. 92, p. 669: "tertio modo potest exponi, sicut iste exponit, ut 'iniquitas' accipiatur ibi pro peccato primorum parentum; et tunc per iniquitatem non accipitur proprie causaliter, sed accipitur occasionaliter"; cf. Miethke, Ockhams Weg (cit. n. 3 above), 485-87. 
terrenorum cure incepit incumbere. legitur quod ista divisio fuit facta prae(...) quod Caym fuerit agricola, hoc cepto diuino; ergo voluntate humana non auctoritate diuina immediate, set fuit prima divisio introducta. sua propria voluntate et cupiditate est factum (...) Et sic divisio rerum inter Caym et Abel per iniquitatem ex altero latere, scilicet ex parte Caym, introducta est...

Offler has already remarked on Ockham's dependence on Francis' Improbatio on this point: ${ }^{45}$ even though he does not copy Francis' exact words in his own text, Ockham is very faithful to his model. Proving that human law, and not divine law, is responsible for establishing property division, Francis of Marchia refers to the case of Cain and Abel, suggesting - on the basis of the Glossa ordinaria - that the division goes back to Cain's corrupted will. As one can easily see from the above example, Ockham reports Francis' argument by "polishing" it, that is dropping the reference to Cain's evil will, which probably seemed to him superfluous in the economy of his reasoning. It is indeed sufficient to show that the mere fact of the division between the two brothers does not dependaccording to the Holy Scripture - on God's will. It must therefore go back to human initiative. Moreover, Francis suggests that "per iniquitatem" can apply to Cain's wicked intention, while Ockham avoids this claim completely, since it could conflict dangerously with the above-mentioned Franciscan interpretations of Dilectissimis.

At any rate, here Ockham follows Francis on the path of a well established Franciscan tradition, one that had already been defended by John Duns Scotus. ${ }^{46}$ For his part, Francis supported this doctrine in his commentary on Book IV of the Sentences, read in Paris in all probability around 1320. ${ }^{47}$ In Quia vir reprobus John had challenged this doctrine, not by

45 See also Miethke, Ockhams Weg (cit. n. 3 above), 484.

${ }^{46}$ I have summarized the discussion about Scotus' text in La povertà pensata (cit. n. 27 above), 113-22, 141-61. For an introduction, see Fohn Duns Scotus' Political and Economic Philosophy, ed. and trans. A.B. Wolter, St. Bonaventure, NY 2001, 1-21 (unfortunately, the Latin text contains several typographical errors that should be removed in the next edition).

${ }^{47}$ On this text, see my Natural Law, Religious Poverty and Ecclesiology according to Francis of Marchia, forthcoming in: J. Meirinhos and M.C. Pacheco (eds.), Intellect et Imagination dans la philosophie médiévale. Actes du XI Congrès International de Philosophie Médiévale de la SIEPM, 
arguing, as many critics of the Friars Minor had done, that the right of ownership is founded on natural law, and not on human positive law, ${ }^{48}$ but by claiming that it rests solely on divine law. ${ }^{49}$ This claim allowed him to deny the validity of the whole Franciscan account of the origins of ownership and to ground ownership in the relationship existing between God and human beings even before the Fall. For Franciscans, on the contrary, it was vital to declare the human origins of ownership, because, as has been noted several times, this was a necessary premise of their theory of the absolute poverty of Christ and, therefore, of their interpretation of Franciscan poverty. ${ }^{50}$

In Ockham's later political writings, such as his Breviloquium, the human origins of ownership would become an essential part of a political theory that denies the divine origin of ownership in order to counter the papal claim to a universal dominium over things and political communities, as Augustinian theologians such as Giles of Rome had argued at the beginning of the century. ${ }^{51}$ In this case, Ockham clearly takes inspiration from Francis' Improbatio, re-elaborates it in the context of the direct controversy with John XXII, and then develops it further, making it a cornerstone of his political thought. ${ }^{52}$

Porto, du 27 au 31 août 2002, Turnhout 2006; but also A proposito del IV libro del Commento alle Sentenze di Francesco d'Appignano: la quaestio 37, in: Atti del II Convegno Internazionale su Francesco d'Appignano (cit. n. 6 above), 9-26.

${ }^{48}$ Cf. V. Mäkinen, Godfrey of Fontaines' Criticism Concerning Franciscan Poverty and the Birth of Individual Rights, in: Picenum seraphicum, 19 (2000), 69-85; cf. also V. Mäkinen, Property Rights in the Late Medieval Discussion on Franciscan Poverty, Leuven 2001, esp. 105-90.

${ }_{49}$ Cf. Quia vir reprobus, in Nicolaus Minorita, Chronica, esp. 590-94.

50 On this issue, see A. Tabarroni, Francescanesimo e riflessione politica sino ad Ockham, in: Etica e politica: le teorie dei frati mendicanti nel Due e Trecento. Atti del XXVI Convegno internazionale. Assisi, 15-17 ottobre 1998, Spoleto 1999, 203-30; cf. Mäkinen, Property Rights (cit. n. 48 above), 162-90; see also my Poverty and Power: Franciscans in Later Mediaeval Political Thought, in: J. Kraye and R. Saarinen (eds.), Moral Philosophy on the Threshold of Modernity, Dordrecht 2004, 141-63.

${ }^{51}$ Cf. Miethke, Ockhams Weg (cit. n. 3 above), 495-96; idem, Ai confini del potere. Il dibattito sulla potestas papale da Tommaso d'Aquino a Guglielmo d'Ockham, trans. C. Storti, Padua 2005, originally De potestate papae. Die päpstliche Amtskompetenz im Widerstreit der politischen Theorie von Thomas von Aquin bis Wilhelm von Ockham, Tübingen 2000.

52 A.S. McGrade, Introduction, in: William of Ockham, A Letter to the Friars Minor and Other Writings, eds. A.S. McGrade and J. Kilcullen, Cambridge et alibi 1995, xiv-xix; Kilcullen, The Political Writings (cit. n. 20 above), 308-09; J. Coleman, A History of Political Thought. From the Middle Ages to the Renaissance, Oxford 2000, 169-98. 


\section{Heathen Kings}

The temporal implications of Christ's kingship was long a debated issue in medieval political thought. ${ }^{53}$ They play a role in the discussion between John and the group around Michael of Cesena only after Quia vir reprobus, because in this decretal the claim that, from his conception, Christ the man was temporal lord of everything is used to reject the thesis that Christ was absolutely poor in his earthly life. After the publication of Quia vir reprobus, this thesis occupies an important place in the list of errors the Michaelists attribute to the pope. ${ }^{54}$ Their endeavors to show that, on the contrary, Christ the man renounced every sort of temporal power over things and over human beings focused not only on scriptural passages stating that Christ was poor, but also on the relationship he seems to have had with the political authorities in the Palestine of his day. In their view, if Christ can be said to have recognized the legitimacy of Roman rule and its governors, he cannot really have been king in any temporal sense of the term, because this would imply a contradiction. To this end they had to challenge another pillar, so to speak, of curialist doctrine, i.e. that no power can be legitimate outside the Church. This theme would acquire a special relevance in Ockham's later works, such as the Breviloquium. ${ }^{55}$ From the following synopsis it is highly probable that Ockham took one of the key arguments for this thesis from the Improbatio:

Improbatio, p. 408

... in eodem regno temporali non possunt nec debent esse simul reges a pari et inconnexi, quia Nemo potest duobus dominis seruire, scilicet inconnexis, secundum Matheum vi. capite: set Cesar, imperator Romanorum, fuit uerus dominus, licet infidelis, in temporalibus, aliter enim Christus uerbo et
Opus Nonaginta Dierum, 93, pp. 683-84

In eodem regno saeculari non possunt esse plures reges veri, non habentes regnum pro indiviso, quorum neuter cognoscit regnum ab altero. Sed imperator Romanorum tempore Christi fuit verus rex Iudaeae, quamvis fuisset rex aliorum regnorum; et constat quod Christus et imperator non tenebant

53 About this issue cf. J. Leclercq, L'idee de la royauté du Christ au Moyen Age, Paris 1959; cf. also my La povertà pensata (cit. n. 27 above), 249-68.

54 Cf. C. Dolcini, Marsilio e Ockham. Il diploma imperiale Gloriosus Deus, la memoria politica Quoniam Scriptura, il Defensor Minor, Bologna 1981, now in idem, Crisi di poteri e politologia in crisi. Da Sinibaldo Fieschi a Guglielmo d'Ockham, Bologna 1988, 343-98.

${ }_{55}$ William Ockham, Breviloquium, 1. III (Opera politica, IV), ed. H.S. Offler, Oxford et alibi 1999, 161-93. On this issue, see A.S. McGrade, The Political Thought of William of Ockham. Personal and Institutional Principles, Cambridge et alibi 1974, esp. 96-103. 
exemplo sibi dari tributum non consuluisset. Christus autem a Cesare regnum temporale non recognouit, licet sibi tributum, non in recognitione regni sed pro uitatione scandali et futuri significatione misterii, dederit, nec Cesar recognouit regnum temporale a Christo in quantum homo, set potius eius ministri exigebant tributum a Christo, ut patet Mathei xvii. capite. regnum Iudaeae pro indiviso, nec Christus cognoscebat regnum Iudaeae ab imperatore nec imperator a Christo. Ergo Christus non fuit verus rex saecularis Iudaeae.

Hic videntur tria probanda. Primum est quod Caesar seu imperator fuit rex Iudaeae. Hoc ex Evangelio elicitur evidenter, Christo dicente: Reddite quae sunt Caesaris, Caesari; ex quibus verbis colligitur quod illa, quae Caesar vendicavit in Iudaea, vere erant sua. Sed Caesar tanquam rex Iudaeae et dominus vendicavit tributum; ergo vere tributum erat ipsius tamquam regis et domini; ergo vere ipse fuit rex. Secundum hic probandum est, quod Caesar non recognoscebat regnum a Christo nec recognoscere tenebatur. Nam ante nativitatem Christi Caesar fuit rex verus; sed per nativitatem Christi regnum Caesaris non fuit in aliquo diminutum nec immutatum nec in aliquam subiectionem redactum; ergo, sicut ante nativitatem Christi non tenebatur ab aliquo homine recognoscere regnum quodcunque, ita post nativitatem Christi non tenebatur ab homine inquantum homo recognoscere regnum; et ita non tenebatur recognoscere regnum a Christo inquantum erat homo.

Tertium quod videtur probandum est, quod Christus non recognoscebat regnum a Caesare. Sed hoc probatione non indiget: cum numquam regnum aliquod vindicaverit, sed rex fieri recusavit...

Again in this context, Ockham re-elaborates Francis' ratio, giving a probatio for some presuppositions that were implicit in the argument of his confrére; on the other hand, he drops the reference to the tribute paid by 
Christ. Indeed, this episode from Matthew evoked interpretations that denied Christ's submission to the emperor, because Jesus says, in the Vulgate, “. . . ergo liberi sunt filii. Ut autem non scandalizemus eos vade ad mare...." ${ }_{56}$ Obviously this suggested an interpretation of this controversial episode which could risk weakening its value as proof for the thesis Francis supported. It is true, in fact, that Francis uses this passage from the Vulgate to show that Christ was not obliged to pay a tribute to the emperor as a subordinated king would have had to. On the other hand, the same episode could be interpreted in the sense that Christ obeyed the Roman emperor not because the latter was a legitimate sovereign, but simply to "avoid scandal". In this perspective, the papal claim could be well founded: Christ was truly a temporal sovereign, but chose, "in order to avoid scandal," to act as if he were not. There are traces of such a use of this episode in the political debate. ${ }^{57}$ In the face of this complexity, the Venerabilis Inceptor probably preferred to avoid the quotation, simply referring to the evidence that Christ never laid claim to a

56 Mt. 17, 26, Biblia sacra iuxta vulgatam versionem, eds. R. Weber et alii, Stuttgart 1994, 1553. This is even clearer in the parallel passage contained in the Appellatio magna, in Nicolaus Minorita, Chronica, pp. 637-8: "Cum Christus fuisset a Iudaeis requisitus utrum tenerentur de iure dare tributum Caesari, respondit, Reddite quae sunt Caesari Caesari et quae sunt Dei Deo, (...) Ex quibus verbis Christi manifeste apparet quod Caesar erat verus rex et dominus in temporalibus, quia sibi Christus, sicut regi, tributum dari iussit. Quod nequaquam fecisset nisi ipsum pro rege vero in temporalibus habuisset, quia prestare tributa est probatio subiectionis X, De censibus, c. 2. Et per consequens Christus non erat rex et dominus in temporalibus, cum duo in solidum reges et domini immediati, quorum neuter subsit alteri, in eodem regno esse nequeant, quia nemo potest duobus dominis servire, ut habetur Matthaei 6, 24. Et 7 causa q. 1, c. In apibus, dicitur: 'Roma condita duos fratres reges simul habere non potuit.' Constat autem quod Christus non recognovit aliquod regnum nec dominium temporale a Caesare, quia licet mandaverit Petro solvere censum ministris Caesaris pro se et pro ipso, non tamen hoc fecit in recognitione alicuius regni nec dominii temporalis quod teneret ab ipso Caesare, sed pro evitatione scandali, ut patet Matthaei 17, 26 et expresse dicitur 28, q. 1 c. Iam nunc. Nec Caesar recognovit aliquod regnum nec dominium temporale a Christo secundum quod homo, sed potius ministri Caesaris exigebant tributum a Christo, ut patet in dicto capitulo Matthaei 17, 23." In principle, it is not impossible that Ockham took his inspiration from the Appellatio; I am inclined to believe that Francis was his model.

57 See for example John of Paris, De potestate regia et papali, c. 8, ed. F. Bleienstein, Stuttgart 1969, 101, where this passage is at first evoked as used by supporters of ecclesiastical exemption from lay power: "Si dicatur quod solvere non tenebatur sed solvit vitare volens scandalum ut dicitur de didrachmate census ..."; the passage was already used for different purposes in Gratian's Decretum: cf. C. XXIII, q. 8, c. 22, and c. XXVIII, q. 1, c. 8, ed. E. Friedberg, Leipzig 1879, respectively cols. 961 and 1082. 
kingdom in his life and even refused to accept the position when it was offered.

From the Improbatio Ockham derived yet another proof that Christ was never king in a temporal sense: the fact that the Gospels never describe Christ as fulfilling his duties as a temporal king. Given this situation, to claim that he was nevertheless king would amount to accusing him of being something similar to a rex inutilis, a commonly discussed issue in political theory..$^{58}$ From a comparison of the Improbatio and the Opus Nonaginta Dierum it becomes clear that, here again, Ockham inserted in his Opus an argument he found in the Improbatio, ${ }^{59}$ formulating it, however, in a rather different way:

Improbatio, pp. 411-12

Quod etiam ratione evidenti patet, quoniam uelle habere nomen alicuius officii et non facere ea que spectant ad illud officium est uelle habere nomen officii sine re: quod non est opus sapientis. Velle enim uocari regem et nolle facere illa que spectant ad opus et officium regis, est uelle habere nomen regis sine re et, per consequens, est usurpare sibi nomen regis: set constat quod Christus in hac vita mortali non exercuit illa que spectant et pertinent ad officium regis temporalis.
Opus Nonaginta Dierum, 93, p. 683

Qui regnum suscipit gubernandum et de regimine ipsius nullo modo se intromittit, quamvis possit, est de malitia seu de nequitia vel negligentia merito arguendus; quia talis vult habere nomen regis, et officium et quae regis sunt minime exercere, quod malitiae vel negligentiae est penitus ascribendum. Sed Christus de saeculari regimine cuiuscunque regni se nullatenus intromisit; ergo vel non suscepit regnum gubernandum, nec fuit rex per consequens: vel fuit de militia vel negligentia arguendus.

${ }^{58}$ Cf. G. Dolcini, Il pensiero politico di Michele da Cesena, 1328-1338, Faenza 1977, now in idem, Crisi di poteri e politologia in crisi (cit. n. 54 above), 147-221, esp. 196-98.

${ }_{59}$ The parallel passage found in the Appellatio magna (in Nicolaus Minorita, Chronica, p. 646) is not as close to Opus Nonaginta Dierum as is the one contained in Improbatio: "Praeterea, cum ad regimen temporalis regis pertineat pugnare bella pro subiectis, malefactores punire, stipendia militibus dare, de haereditatibus et successionibus temporalibus disponere et ordinare, et similia facere (...) de quibus certum est quod Christus, in quantum homo viator, in hac vita sic se nullatenus intromisit, sequitur quod Christus non rexit populum sibi commissum temporaliter sed spiritualiter, quare non fuit rex et dominus in temporalibus, alioquin in regendo fuisset negligens et remissus"; cf. also ibid., p. 666. 


\section{Conclusion}

At a point in time that we have not yet ascertained, Francis and Ockham again parted their ways. At the end of a trial during which Francis at first tried in vain to defend his views, the Franciscan from Appignano repented in $1343 .{ }^{60}$ Ockham remained in Munich, faithful to his positions until death. Their legacies in the history of medieval thought also had differing destinies: Ockham's philosophical style exerted an enormous influence, even though many of his specific solutions to philosophical and theological problems were rejected. ${ }^{61}$ Francis of Marchia's philosophical theology played an important role in debates for many years, but in a much less sensational manner, so that his actual importance is still under investigation. ${ }^{62}$ In the specific field of political theory, the success that Ockham's writings enjoyed helped to cast Francis' Improbatio in an almost perennial shade, from which it was freed by Offler and it is finally receiving the attention it deserves only since the publication of Mariani's edition.

At the present state of knowledge, we can reconstruct the basic outline of the complex relationship between the two Franciscan authors. Their first encounter took place in the early 1320s when Francis of Marchia squarely rejected the doctrines concerning the categories and the Eucharist defended by a confrère active in England. The commitment of both friars to the cause of Michael of Cesena changed the situation radically. They contributed together to some collective works, but it was Francis, this time, who would be used by Ockham. The attitude of the Venerabilis Inceptor towards the Improbatio was multi-faceted. On the one hand, he clearly chose a different strategy, avoiding violent polemics and

${ }^{60}$ Cf. E.L. Wittneben and R. Lambertini, Un teologo francescano alle strette. Osservazioni sul testimone manoscritto del processo a Francesco d'Ascoli, in: Picenum seraphicum, 18 (1999), 97-122, and Un teologo francescano alle strette. II. A proposito della tradizione manoscritta della confessio di Francesco d'Ascoli, in: Picenum seraphicum, 19 (2000), 135-49.

${ }^{61}$ For interesting insights into this multi-faceted issue, see W.J. Courtenay, The Reception of Ockham's Thought at the University of Paris, in: Z. Kaluza and P. Vignaux (eds.), Preuve et raisons à l'Université de Paris, Paris 1984, 43-84; idem, The Reception of Ockham's Thought in 14th Century England, in: A. Hudson and M. Wilks (eds.), From Ockham to Wyclif, Oxford 1987, 89-107; K.H. Tachau, Vision and Certitude in the Age of Ockham: Optics, Epistemology and the Foundations of Semantics, 1250-1345, Leiden 1988.

62 Scholars of medieval thought possess a deep investigation of Francis' influence in C. Schabel, Theology at Paris, 1316-1345. Peter Auriol and the Problem of Divine Foreknowledge and Future Contingents, Aldershot 2000, esp. 189-220, 324-36; but one should not forget Russell Friedman's contribution to the re-discovery of the theologian from Appignano. 
personal attacks; on the other, although modifying many of Francis' texts and arguments, he undeniably took from the Improbatio some key elements that were to become central not only to his Opus Nonaginta Dierum, but also to his political thought in general, as emerges in his later works. If Ockham was among the adversaries implicitly referred to in Francis' Commentary on the Sentences, the latter's Improbatio is a source, in its proper meaning, of Ockham's political theory.

Macerata

Università degli studi di Macerata 